
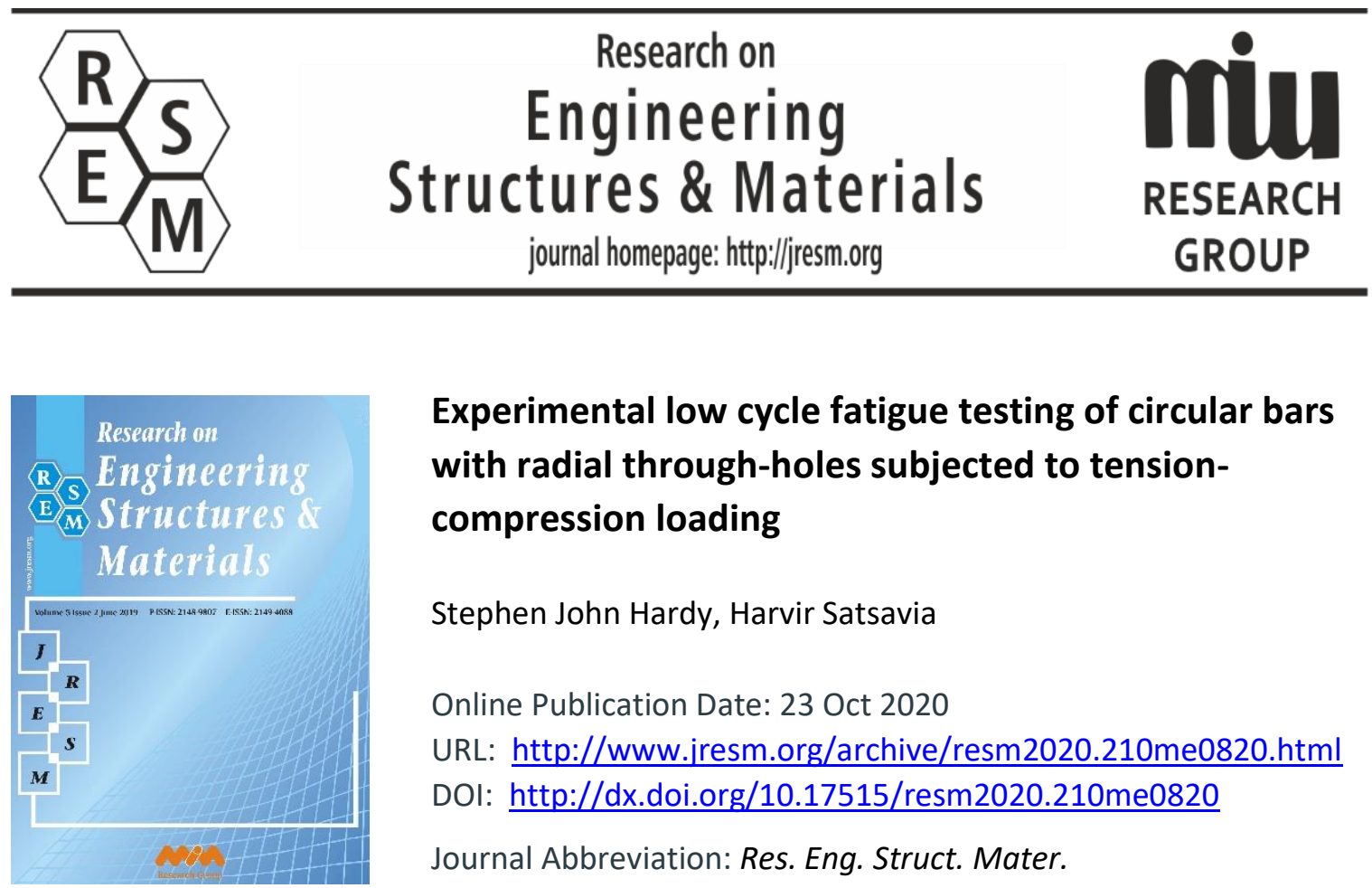

\title{
Experimental low cycle fatigue testing of circular bars with radial through-holes subjected to tension- compression loading
}

Stephen John Hardy, Harvir Satsavia

Online Publication Date: 23 Oct 2020

URL: http://www.jresm.org/archive/resm2020.210me0820.html

DOI: http://dx.doi.org/10.17515/resm2020.210me0820

Journal Abbreviation: Res. Eng. Struct. Mater.

\section{To cite this article}

Hardy S J, Satsavia H. Experimental low cycle fatigue testing of circular bars with radial through-holes subjected to tension-compression loading. Res. Eng. Struct. Mater., 2021; 7(1): 87-95.

\section{Disclaimer}

All the opinions and statements expressed in the papers are on the responsibility of author(s) and are not to be regarded as those of the journal of Research on Engineering Structures and Materials (RESM) organization or related parties. The publishers make no warranty, explicit or implied, or make any representation with respect to the contents of any article will be complete or accurate or up to date. The accuracy of any instructions, equations, or other information should be independently verified. The publisher and related parties shall not be liable for any loss, actions, claims, proceedings, demand or costs or damages whatsoever or howsoever caused arising directly or indirectly in connection with use of the information given in the journal or related means.

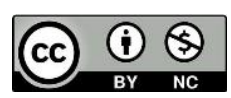

Published articles are freely available to users under the terms of Creative Commons Attribution - NonCommercial 4.0 International Public License, as currently displayed at here (the "CC BY - NC"). 


\title{
Research on Engineering Structures \& Materials
}

journal homepage: http://jresm.org

Research Article

\section{Experimental low cycle fatigue testing of circular bars with radial through-holes subjected to tension-compression loading}

\author{
Stephen John Hardy, $, 1, \mathrm{a}$, Harvir Satsavia ${ }^{2, \mathrm{~b}}$ \\ ${ }^{1}$ College of Engineering, Swansea University, Bay Campus, Swansea, UK \\ ${ }^{2}$ Redstone Rail, Royal Leamington Spa, UK

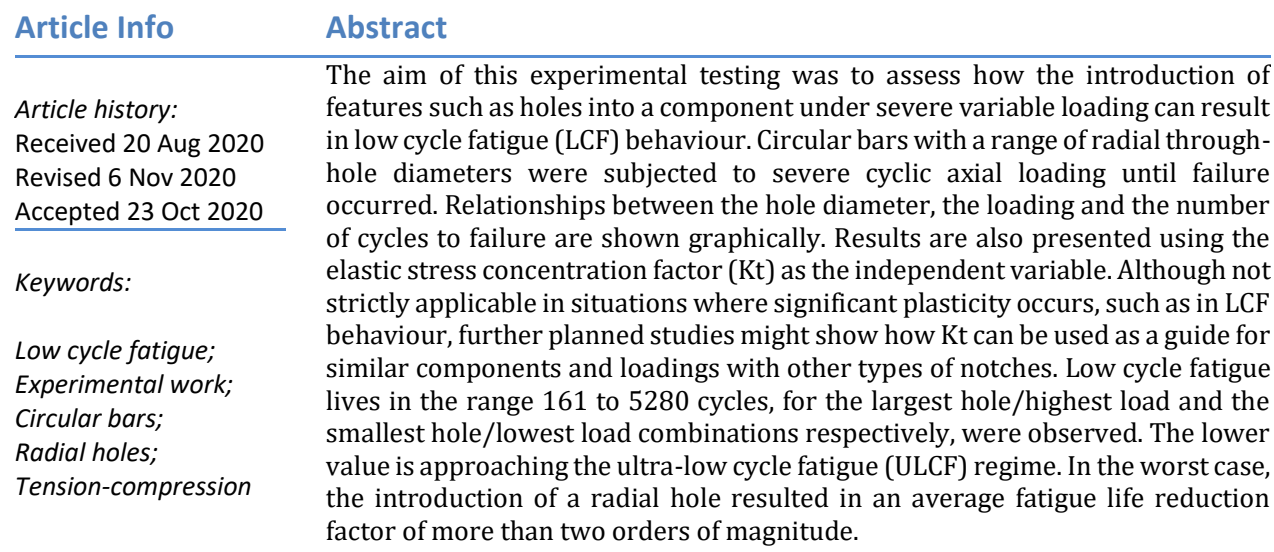

(C) 2021 MIM Research Group. All rights reserved.

\section{Introduction}

Geometric discontinuities such as shoulders, holes, grooves, threads, etc. induce local high (above average) stresses. These stress raisers are generally termed 'notches'. In a variable loading regime, Fatigue Crack Initiation (FCI) and subsequent propagation can occur at the roots of these notches. Since most engineering components contain notches of some form or another, design assessment methods for these components must take account of any such stress raisers. Many instances of mechanical failure can be attributed to inadequate design in the region of a discontinuity. It has been estimated that up to $90 \%$ of all structural failures have fatigue as the root cause of failure [1]. An early example is the fatigue failure of railway axles, which became a problem in the middle of the 19th century and drew attention to the effects of cyclic loading. It was the first instance in which components had been exposed to millions of cycles at differing stress levels thus causing fatigue defects.

Although a component may satisfy static design considerations, High Cycle Fatigue (HCF) can occur under low to moderate variable loading. This can take many cycles, typically $10^{6}$ or more. However, under moderate to high variable loading, notches are likely sites for plastic deformation and fatigue failure can occur in significantly fewer cycles e.g. $10^{4}$ or less. This is referred to as Low Cycle Fatigue (LCF) and the LCF behaviour of notched components is a complex problem, which has been modelled extensively and remains of great interest. From an analytical viewpoint, LCF life predictions are based on a local strain

${ }^{*}$ Corresponding author: $\underline{\text { s.j.jhardy@swansea.ac.uk }}$

a orcid.org/0000-0003-3899-9174; b orcid.org/0000-0002-0615-9069

DOI: http://dx.doi.org/10.17515/resm2020.210me0820

Res. Eng. Struct. Mat. Vol. 7 Iss. 1 (2021) 87-95 
approach, e.g. Dowling et al [2] and Topper and Gowda [3], using experimental fatigue data from simple uniaxial un-notched specimen tests. A useful review of life prediction techniques is provided by Agrawal et al [4]. They consider smooth and notched specimens at both room and elevated temperature. Although the authors focus on predictive techniques, they acknowledge the importance of experimental testing to support these predictive techniques. Although powerful computation methods, such as finite element analysis, can be used to predict LCF life, there is still a considered need for experimental data to support the predictions.

In this paper, the experimental LCF testing of circular bars with radial through-holes subjected to cyclic axial loading is described and the effects of hole size and loading level are quantified and compared with un-notched specimens. Gowhari-Anaraki et al [5] have previously described experimental LCF testing of notched circular shafts in bending, where the effect of external notches is quantified and the fatigue lives are compared with estimates using the simple notch stress-strain conversion rules (Neuber, linear). Recently, Dundulis et al [6] have carried out low cycle fatigue testing on plain circular bars made from P91 steel subjected to strain controlled high temperature axial loading. Unlike the work reported here, where specific stress concentration features generate high local levels of total strain range, low cycle fatigue is induced by the high level of bulk total strain range (up to 1\%) being applied. The authors demonstrate good comparison between the experimental results and those estimated using the Manson-Coffin-Basquin equation. Recently, Beesley et al [7] have proposed an analytical method for predicting shakedown, ratchetting and crack initiation loads of notched components using a circular bar with scalloped edges containing a chamfered through-hole. They plan to carry out experimental testing to determine the LCF life of these components. As yet, this work has not been reported but will be of significant interest to the authors of this paper.

\section{Experimental Components and Testing Method}

Low cycle fatigue testing was undertaken using a Zwick HA 250kN hydraulic fatigue testing machine, as shown in Figure 1. Tensile specimens with a gauge diameter of $12 \mathrm{~mm}$ were manufactured from M20, EN8 steel screwed bar. Typical material properties for tempered EN8 are shown in Table 1.

Table 1 Typical tempered EN8 material properties

\begin{tabular}{cccccccc}
\hline $\begin{array}{c}\text { Young's } \\
\begin{array}{c}\text { Modulus } \\
(\mathrm{GPa})\end{array}\end{array}$ & $\begin{array}{c}\text { Poisson's } \\
\text { Ratio }\end{array}$ & $\begin{array}{c}\text { Yield } \\
\text { Stress } \\
(\mathrm{MPa})\end{array}$ & $\begin{array}{c}\text { UTS } \\
(\mathrm{MPa})\end{array}$ & $\begin{array}{c}\text { \%age } \\
\text { Elongation }\end{array}$ & $\begin{array}{c}0.2 \% \\
\text { Proof } \\
\text { tress } \\
\text { (MPa) }\end{array}$ & $\begin{array}{c}\text { Brinell } \\
\text { Hardness }\end{array}$ & $\begin{array}{c}\text { KCV } \\
\text { Impact } \\
\text { Toughness } \\
(\mathrm{J})\end{array}$ \\
\hline 190 & 0.3 & 465 & $\begin{array}{c}700- \\
850\end{array}$ & 16 & 450 & $201-255$ & 28 \\
\hline
\end{tabular}

Four types of specimen were tested:

1. A plain fatigue specimen, machined from the screwed bar, nominal diameter $=12 \mathrm{~mm}$ (see Fig. 2);

2. As specimen 1 with a central $2.4 \mathrm{~mm}$ diameter radial through-hole;

3. As specimen 1 with a central $4.2 \mathrm{~mm}$ diameter radial through-hole;

4. As specimen 1 with a central $6.0 \mathrm{~mm}$ diameter radial through-hole.

A tensile test was carried out on each type of specimen in order to estimate the load at which plastic deformation began from which an approximate 'yield load' was determined.

For the fatigue testing, fully reversed sine wave loading at $1 \mathrm{~Hz}$ was carried out at $80 \%$, $75 \%, 70 \%, 65 \%$ and $60 \%$ of this 'yield load'. 


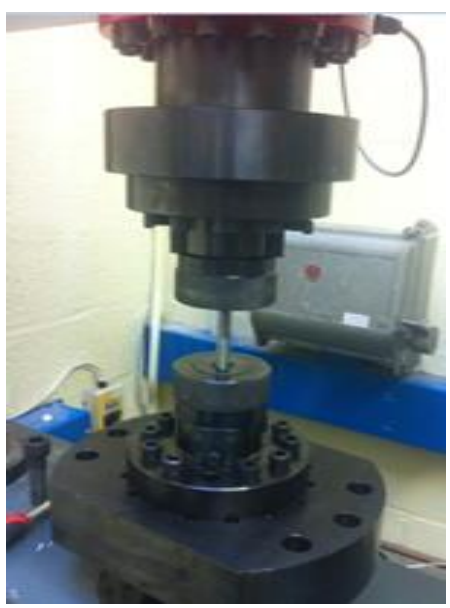

Fig. 1 Zwick HA 250kN hydraulic fatigue testing machine
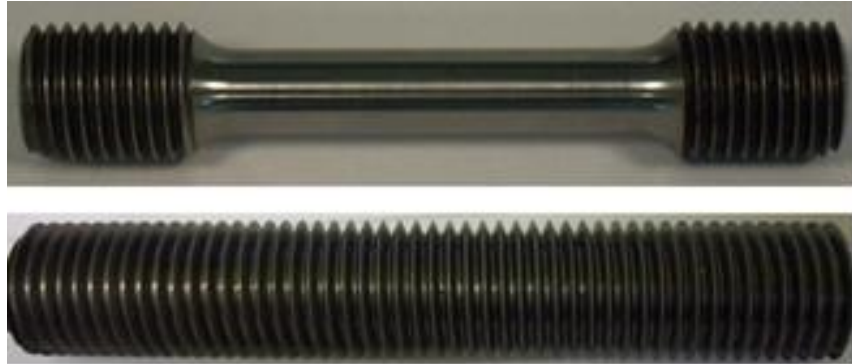

Fig. 2 Fatigue specimens and original screwed bar

\section{Experimental Results}

Initial tensile testing of specimen types 1, 2, 3 and 4 produced 'yield loads' of 53, 40, 32 and $22 \mathrm{kN}$ respectively. These values were then used for the fatigue tests.

The results of the fatigue tests are shown in Table 2. For the plain specimen, the fatigue lives for $65 \%$ and $60 \%$ of the 'yield load' are in the transition region between LCF and HCF, and these tests were not repeated. For all other tests, the fatigue lives are within the LCF region. The value in brackets after the average value is a measure of the repeatability and is obtained by the Equation 1:

$$
\% \text { discrepancy }=\frac{\left(\text { higher } N_{f}-\text { lower } N_{f}\right)}{\text { average } N_{f}} \times 100
$$

With a few notable exceptions, the test-to-test discrepancies are within reasonable bounds for experimental testing. The number of cycles to failure for the bar with the $6 \mathrm{~mm}$ diameter hole and a load of $80 \%$ of the 'yield load' is approaching a region referred to as Ultra-Low Cycle Fatigue (ULCF) , which is often set at $\mathrm{N}_{\mathrm{f}}<100$ cycles [8]. 
Table2 Fatigue Test Results

\begin{tabular}{|c|c|c|c|c|c|c|}
\hline \multirow{3}{*}{$\begin{array}{l}\text { Percentage } \\
\text { of yield } \\
\text { load }\end{array}$} & \multicolumn{6}{|c|}{ Test Specimens } \\
\hline & Plain Bar & \multicolumn{2}{|c|}{$\begin{array}{c}2.4 \mathrm{~mm} \\
\text { diameter hole }\end{array}$} & \multicolumn{2}{|c|}{$\begin{array}{c}4.2 \mathrm{~mm} \\
\text { diameter hole }\end{array}$} & $\begin{array}{c}6.0 \mathrm{~mm} \\
\text { diameter hole }\end{array}$ \\
\hline & \multicolumn{6}{|c|}{ Number of cycles to failure $\left(\mathrm{N}_{\mathrm{f}}\right)$} \\
\hline \multirow{3}{*}{$80 \%$} & Test 1 & Test 1 & Test 2 & Test 1 & Test 2 & Test 1 \\
\hline & $331 \quad 416$ & 283 & 291 & 222 & 252 & $161 \quad 175$ \\
\hline & $\begin{array}{c}\text { Average }=373.5 \\
(23 \%) \\
(\text { Load }=42.4 \mathrm{kN})\end{array}$ & \multicolumn{2}{|c|}{$\begin{array}{c}\text { Average }=287 \\
(3 \%) \\
(\text { Load }=32.0 \\
\mathrm{kN})\end{array}$} & \multicolumn{2}{|c|}{$\begin{array}{c}\text { Average }=237 \\
(13 \%) \\
(\text { Load }=25.6 \\
\mathrm{kN})\end{array}$} & $\begin{array}{c}\text { Average }=168 \\
(8 \%) \\
(\text { Load }=17.6 \\
\mathrm{kN})\end{array}$ \\
\hline \multirow{3}{*}{$75 \%$} & Test 1 & Test 1 & Test 2 & Test 1 & Test 2 & $\begin{array}{ll}\text { Test } 1 & \text { Test } 2 \\
\end{array}$ \\
\hline & 1041 & 466 & 754 & 330 & 215 & 224 \\
\hline & $\begin{array}{c}\text { Average }=995 \\
(9 \%) \\
(\text { Load }=39.75 \\
\mathrm{kN})\end{array}$ & \multicolumn{2}{|c|}{$\begin{array}{c}\text { Average }=610 \\
(47 \%) \\
(\text { Load }=30.0 \\
\mathrm{kN})\end{array}$} & \multicolumn{2}{|c|}{$\begin{array}{c}\text { Average }= \\
272.5(42 \%) \\
(\text { Load }=24.0 \\
\mathrm{kN})\end{array}$} & $\begin{array}{c}\text { Average }=234 \\
(9 \%) \\
(\text { Load }=16.5 \\
k N)\end{array}$ \\
\hline \multirow{3}{*}{$70 \%$} & Test $1 \quad$ Test 2 & Test 1 & Test 2 & Test 1 & Test 2 & Test 1 Test 2 \\
\hline & $5048 \quad 5028$ & 1902 & 1453 & 361 & 305 & $240 \quad 335$ \\
\hline & $\begin{array}{c}\text { Average }=5038 \\
(0.4 \%) \\
(\text { Load }=37.1 \mathrm{kN})\end{array}$ & \multicolumn{2}{|c|}{$\begin{array}{c}\text { Average }= \\
1677.5(27 \%) \\
(\text { Load }=28.0 \\
\text { kN })\end{array}$} & \multicolumn{2}{|c|}{$\begin{array}{c}\text { Average }=333 \\
(17 \%) \\
(\text { Load }=22.4 \\
\mathrm{kN})\end{array}$} & $\begin{array}{c}\text { Average }= \\
287.5(33 \%) \\
(\text { Load }=15.4 \\
\mathrm{kN})\end{array}$ \\
\hline \multirow{3}{*}{$65 \%$} & Test 1 & Test 1 & Test 2 & Test 1 & Test 2 & Test 1 Test 2 \\
\hline & 22631 & 2748 & 2337 & 589 & 497 & 284 \\
\hline & $\begin{array}{c}\text { Average }=22631 \\
(-) \\
(\text { Load }=34.45 \\
\mathrm{kN})\end{array}$ & \multicolumn{2}{|c|}{$\begin{array}{c}\text { Average }= \\
2542.5(16 \%) \\
(\text { Load }=26.0 \\
\mathrm{kN})\end{array}$} & \multicolumn{2}{|c|}{$\begin{array}{c}\text { Average }=543 \\
(17 \%) \\
(\text { Load }=20.8 \\
\mathrm{kN})\end{array}$} & $\begin{array}{c}\text { Average }=344 \\
(35 \%) \\
(\text { Load }=14.3 \\
\mathrm{kN})\end{array}$ \\
\hline \multirow{3}{*}{$60 \%$} & Test $1 \quad$ Test 2 & Test 1 & Test 2 & Test 1 & Test 2 & Test 1 Test 2 \\
\hline & $57211 \quad-$ & 5280 & 3750 & 787 & 1136 & $\begin{array}{ll}648 & 404 \\
\end{array}$ \\
\hline & $\begin{array}{c}\text { Average }=57211 \\
(-) \\
(\text { Load }=31.8 \mathrm{kN})\end{array}$ & $\begin{array}{r}\text { Avera } \\
\text { (Loa } \\
\end{array}$ & $\begin{array}{l}=4515 \\
\%) \\
=24.0\end{array}$ & $\begin{array}{r}\text { Ave } \\
961.5 \\
\text { Loac } \\
\mathrm{k}\end{array}$ & $\begin{array}{l}\text { age }= \\
(36 \%) \\
=19.2 \\
\text { V) } \\
\end{array}$ & $\begin{array}{c}\text { Average }=526 \\
(46 \%) \\
(\text { Load }=13.2 \\
\mathrm{kN})\end{array}$ \\
\hline
\end{tabular}

The results are also presented in graphical form in Figures 3 and 4 for \% 'yield load' against $\log _{10} \mathrm{~N}_{\mathrm{f}}$ and load against $\log _{10} \mathrm{~N}_{\mathrm{f}}$ respectively. From Figure 3:

- $\quad$ Trends of increasing $\mathrm{N}_{\mathrm{f}}$ with reducing \% 'yield load' are as expected;

- There is a small degree of overlap for the 75\% 'yield load' results but they are within reasonable expectations of experimental discrepancy;

- Although in the transition region, the three highest $\mathrm{N}_{f}$ results for the plain specimen appear to follow the general trend;

- The results appear to converge as 'yield load' increases, including the results for the plain specimen;

- As expected, the specimen with the $6 \mathrm{~mm}$ hole has the lowest $\mathrm{N}_{\mathrm{f}}$ values and the plain specimen has the highest $\mathrm{N}_{\mathrm{f}}$ values. and from Figure 4:

- Again, the trends are clear but, in this case, the overlap for the 75\% 'yield load' is not apparent here. 


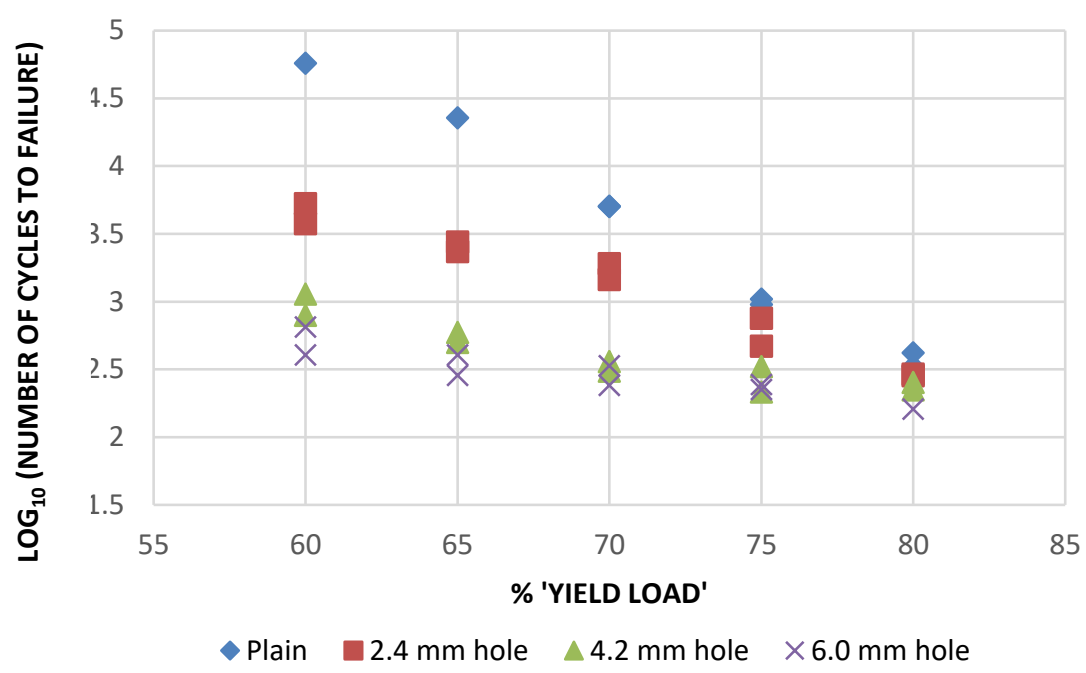

Fig. 3 The variation of $\log _{10} \mathrm{~N}_{\mathrm{f}}$ against \% 'Yield Load'

The variation of $\log _{10} \mathrm{~N}_{\mathrm{f}}$ with hole size is shown in Figure 5 for all tests and the range of loads considered. These results are also presented against elastic stress concentration factor, $\mathrm{K}_{\mathrm{t}}$, in Figure 6. Figure 5 can be used to enable interpolation for hole sizes between those considered in the experiments. Although not strictly applicable in situations where significant plasticity occurs, such as in LCF behaviour, further planned studies might show how $\mathrm{K}_{\mathrm{t}}$ can be used as a 'guide' for similar components and loadings with other types of notches.

The variation of $\log _{10}\left(\mathrm{~N}_{\mathrm{fu}} / \mathrm{N}_{\mathrm{fn}}\right)$ with $\mathrm{K}_{\mathrm{t}}$, where $\mathrm{N}_{\mathrm{fu}}$ is the average number of cycles to failure from Tests 1 and 2 for the un-notched (plain) specimen and $N_{f n}$ is the average number of cycles to failure from Tests 1 and 2 for the notched (holed) specimen at the same load, is shown in Figure 7. The results show a reduction factor in $\mathrm{N}_{\mathrm{f}}$ of between 1.3 and 12.7 for the $2.4 \mathrm{~mm}$ diameter hole, between 1.6 and 59.5 for the $4.2 \mathrm{~mm}$ diameter hole and between 2.2 and 108.8 for the $6.0 \mathrm{~mm}$ diameter hole.

Finally, Figures 8 and 9 are examples of failed specimens. In all cases, fatigue crack initiation starts at the inside surface of the hole followed by varying degrees of crack propagation (shiny, granular regions) until brittle fracture (dull regions with a fibrous appearance) occurs at the point where the remaining cross-section is unable to withstand the load. 


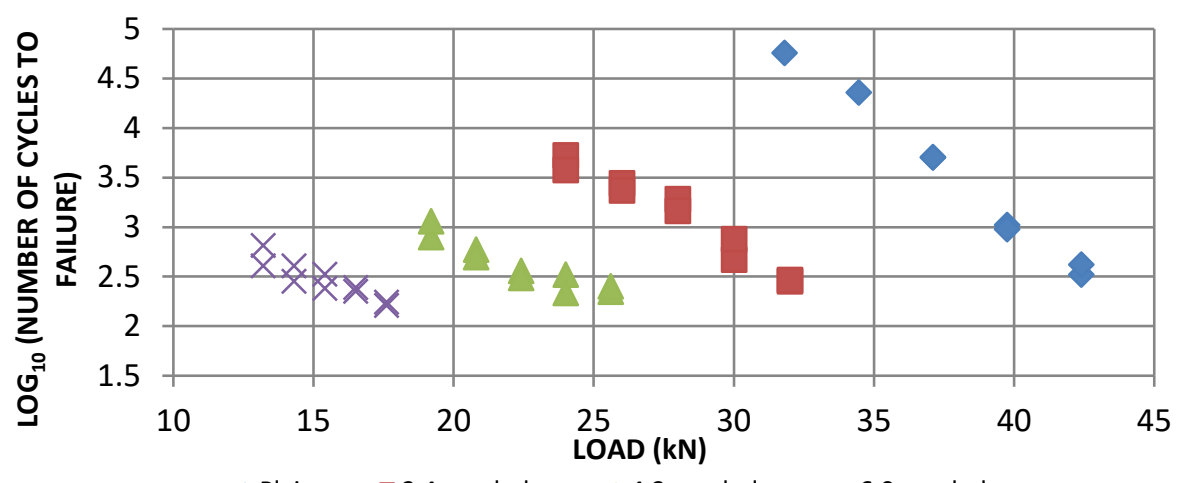

$\diamond$ Plain $\quad 2.4 \mathrm{~mm}$ hole $\quad \Delta .2 \mathrm{~mm}$ hole $\quad \times 6.0 \mathrm{~mm}$ hole

Fig. 4 The variation of $\log _{10} \mathrm{~N}_{\mathrm{f}}$ against Load

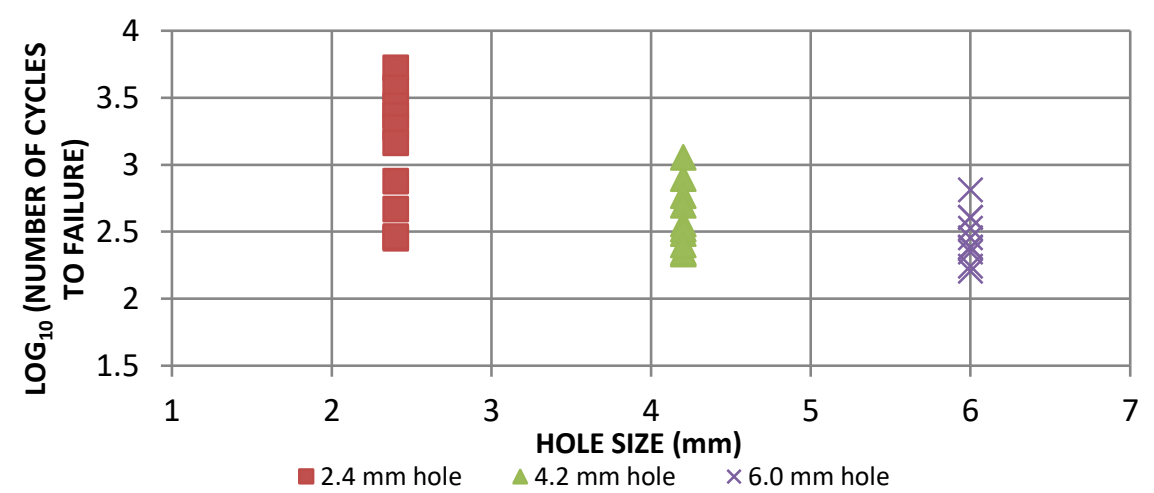

Fig. 5 The variation of $\log _{10} \mathrm{~N}_{\mathrm{f}}$ against Hole Size for the range of loads (increasing load $\downarrow)$

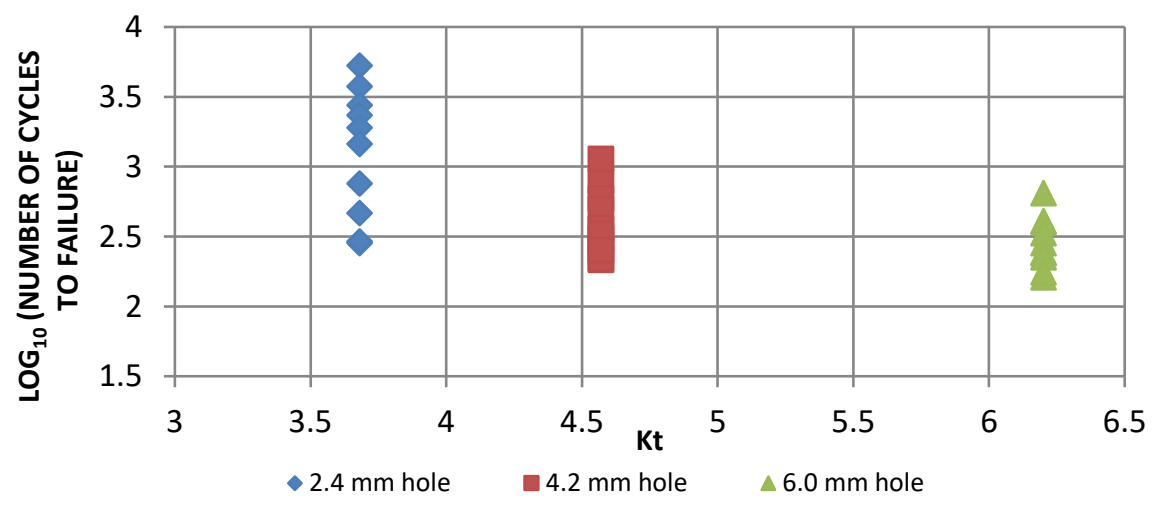

Fig. 6 The variation of $\log _{10} \mathrm{~N}_{\mathrm{f}}$ against $\mathrm{K}_{\mathrm{t}}$ for the range of loads (increasing load $\downarrow$ ) 


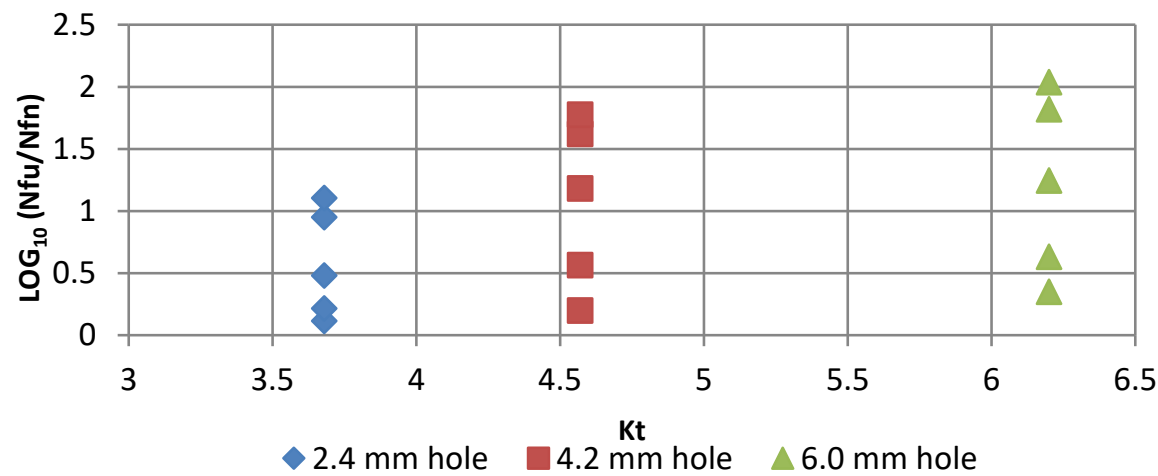

Fig. 7 The variation of $\log _{10}\left(\mathrm{~N}_{\mathrm{fu}} / \mathrm{N}_{\mathrm{fn}}\right)$ against $\mathrm{K}_{\mathrm{t}}($ increasing load $\downarrow)$

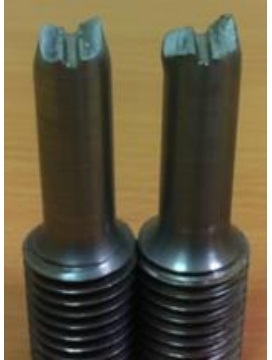

(a) $2.4 \mathrm{~mm}$ hole

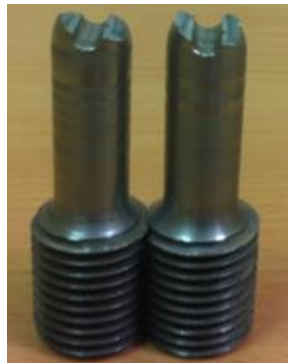

(b) $4.2 \mathrm{~mm}$ hole

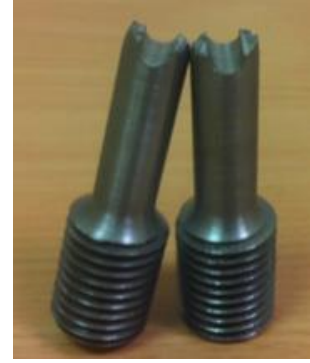

(c) $6.0 \mathrm{~mm}$ hole

Fig. 8 Examples of failed specimens for a load of $80 \%$ of the 'Yield Load'

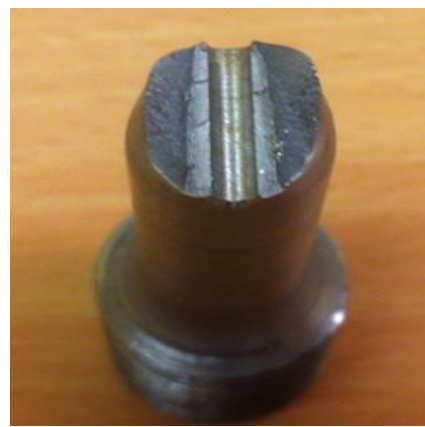

(a) $2.4 \mathrm{~mm}$ hole

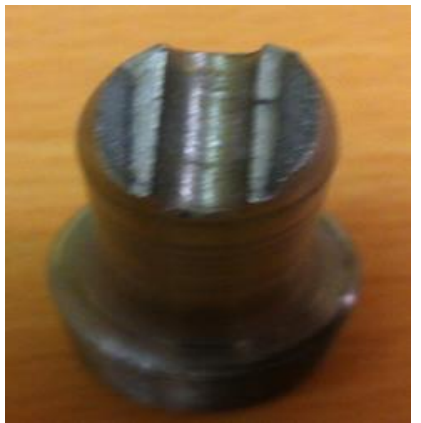

(b) $6.0 \mathrm{~mm}$ hole

Fig. 9 Enlarged views of failed specimens for a load of $80 \%$ of the 'Yield Load'

\section{Discussion}

With the availability of affordable high-power computers, access to finite element analysis to model highly complex problems such as fatigue and to generate very accurate predictions has revolutionised the design process. Nevertheless, there is a danger in relying totally on such predictive techniques. This is particularly true when modelling the elastic-plastic properties of materials in a variable/cyclic loading regime, such as in low 
cycle fatigue. The need for physical evidence to support numerical predictions is, therefore, highly desirable (even essential).

Experimental testing can be very expensive, both in time and resources. This is particularly true for high cycle fatigue testing, where individual tests can run for several months. Low cycle fatigue tests, on the other hand, take far less time to complete and, for reasons explained above, provide valuable evidence to support the design process for components operating in a potentially low cycle fatigue loading regime.

Whereas numerical predictions are 'right-first-time', experimental testing is subject to variability for otherwise identical tests. Care must be taken to minimise this variation. With a few notable exceptions, the experimental results presented in this paper show good repeatability and can instil a reasonable degree of confidence in those results.

The presence of notches such as holes, shoulders, grooves etc. result in a significant increase in the local stress and these stress raisers can, under fatigue loading conditions, result in low cycle fatigue even at moderate loading. A fundamental understanding of the effects of these notches on fatigue behaviour, using simple components, is vitally important to the designer, who needs to be aware that the introduction of a notch will reduce the fatigue life and can well change a high cycle fatigue problem to one of low cycle fatigue, the more complex modelling of which has been previously discussed. It is worth noting that holes are sometimes introduced at a later stage and a new design assessment must be undertaken.

This paper examines the effects of stress raisers in simple components subjected to a fatigue loading regime, in this example plain circular bars/shafts with radial through-holes subjected to cyclic axial loading. Three different hole sizes, namely $2.4 \mathrm{~mm}, 4.2 \mathrm{~mm}$ and 6.0 mm diameter, were drilled into a $12 \mathrm{~mm}$ diameter gauge section of EN8 screwed bar. Tests were carried out at loads of $80 \%, 75 \%, 70 \%, 65 \%$ and $60 \%$ of the 'yield load' (defined as the load at which non-linear material behaviour just starts). Similar tests were also performed on plain bars in order to compare and quantify the effects of the introduction of the holes.

Apart from a few anomalies, both the repeatability and consistency of the results are within acceptable bounds. For a given load level, the least number of cycles to failure corresponds to the largest hole size, as expected.

Figures 3, 4 and 5 can be interpolated for values between the loads and hole sizes considered here. Furthermore, results for other notch types can be added to Figures 6 and 7 to see if the elastic stress concentration factor, $\mathrm{K}_{\mathrm{t}}$, can be used as a simple normalising parameter, bearing in mind that $\mathrm{K}_{\mathrm{t}}$ is only directly applicable for elastic conditions and LCF can be associated with significant plasticity.

\section{Conclusions}

The results have confirmed known qualitative information and have quantified this information for plain bars with radial through-holes subjected to axial tensioncompression low cycle fatigue loading. The main conclusions from the work are:

- The introduction of a hole has reduced the fatigue life of the bar. In the worst case, the introduction of a $6 \mathrm{~mm}$ diameter hole for a load of $60 \%$ of the 'yield load' has reduced the fatigue life by more than two orders of magnitude, Furthermore, whereas the plain bar was in the transition region between LCF and HCF, the hole has brought the fatigue behaviour well within the LCF regime. The smallest reduction in fatigue life observed, for a $2.4 \mathrm{~mm}$ diameter hole and a load of $80 \%$ of the 'yield load', is a factor of 1.3 . This is an interesting result which might not be obvious at first sight but it must be 
remembered that the fatigue life of the plain bar has also reduced significantly at this very high load.

- For any given \% 'yield load', the larger the hole the greater the reduction in fatigue life. The greatest reductions are seen at the 60\% 'yield load' (as explained above) and the level of reduction depends significantly on the hole size. The higher the load, the less the effect of the hole size itself.

- The smaller the hole, the greater the effect of the actual load on the fatigue life. For the $2.4 \mathrm{~mm}$ diameter hole, $\log _{10} \mathrm{~N}_{\mathrm{f}}=2.4 \rightarrow 3.8$ over the range of loads and for the $6.0 \mathrm{~mm}$ diameter hole, $\log _{10} \mathrm{~N}_{\mathrm{f}}=2.2 \rightarrow 2.8$.

- The number of cycles to failure for the largest hole together with the highest load is approaching the ultra-low cycle fatigue regime.

\section{Abbreviations}

$\begin{array}{ll}\text { FCI } & \text { Fatigue Crack Initiation } \\ \mathrm{HCF} & \text { High Cycle Fatigue } \\ \mathrm{LCF} & \text { Low Cycle Fatigue } \\ \mathrm{N}_{\mathrm{f}} & \text { Number of cycles to failure } \\ \mathrm{ULCF} & \text { Ultra-Low Cycle Fatigue }\end{array}$

\section{References}

[1] Sachs NW. Practical plant failure analysis: a guide to understanding machinery deterioration and improving equipment reliability, $2^{\text {nd }}$ edition, Boca Raton CRC Press Taylor and Francis Group, 2019, ISBN 13:978 - 1 - 138 - 32411 - 4.

[2] Dowling NE, Brose WR, Wilson WK. Notched member fatigue life prediction by the local strain approach. Advances in Engineering, 1977, 6: 55-84.

[3] Topper TH, Gowda CVBG. Local stress/strain approach to fatigue analysis and design. ASME Design engineering conference and show, Paper 70-DE-24, Chicago, 1970.

[4] Agrawal R, Uddanwadiker R, Padole P. Low cycle fatigue life prediction. Int J Emerging Engineering Research and Technology, 2014, 2(4): 5-15.

[5] Gowhari-Anaraki AR, Hardy SJ, Pipelzadeh MK. Experimental and analytical fatigue data for notched shafts in bending. Jurnal Kejuruteraan (University Kebangsaan Malaysia), 2003, 15: 15-31.

[6] Dundulis G, Janulionis R, Grybenas A, Makarevicius V, Dundulis R. Numerical and experimental investigation of low cycle fatigue behaviour in P91 steel. Eng Failure Analysis, 2017, 79: 285-295. https://doi.org/10.1016/i.engfailanal.2017.05.001

[7] Beesley R, Chen H, Hughes M. A novel simulation for the design of a low cycle fatigue experimental testing programme. Computers and Structures, 2017, 178: 105-118. https://doi.org/10.1016/j.compstruc.2016.09.004

[8] Pereira JCR, de Jesus AMP, Xavier J, Fernandes AA. Ultra low-cycle fatigue behaviour of a structural steel. Eng Structures, 2014, 60: 214-222. https://doi.org/10.1016/j.engstruct.2013.12.039 